SISTEMA
ELETRÔNICO
DE REVISTAS
SER I UFPR

\title{
Governing complexity and environmental justice: lessons from the water crisis in Metropolitan São Paulo (2013-2015)
}

\section{Governando a complexidade e justiça ambiental: lições da crise da água na região metropolitana de São Paulo (2013-2015)}

\author{
Pedro Henrique Campello TORRES ${ }^{1 *}$, Pedro Luiz CÔRTES ${ }^{1,2}$, Pedro Roberto JACOBI ${ }^{1}$ \\ ${ }^{1}$ Instituto de Energia e Ambiente (IEE), Universidade de São Paulo (USP), São Paulo, SP, Brasil. \\ ${ }^{2}$ Escola de Comunicação e Artes (ECA), Universidade de São Paulo (USP), São Paulo, SP, Brasil. \\ *E-mail of contact: pedrotorres@usp.br
}

Article received on February 4, 2019, final version accepted on December 20, 2019, published on April, 15, 2020.

ABSTRACT: The paper presents a discussion on the water crisis that occurred between 2013 and 2015 in the Metropolitan Region of São Paulo, the lack of integrated natural resources planning, and the reaction of social actors affected by the crisis. The region was affected by an extreme hydrological and climatological event, which was combined with the unsustainable management of water resources. The paper addresses, initially, the dynamics of water governance in the region, and the main aspects related to water availability and climate dependence that caused the water crisis. Then, we present an analysis of the process that led to the water crisis and its main developments, which is based on the follow-up of the different moments of the crisis and dialogues with its relevant stakeholders. The results indicate the relevance of emphasizing issues on matters such as the lack of transparency and highlight the role of societal initiatives. We conclude the paper with a proposition to discuss governance processes that can contribute to the development of more effective initiatives in order to reduce the impact of this visible change in water regimes, strengthen transparent management, and promote a more democratic interaction between social actors and the government.

Keywords: water governance; environmental justice; São Paulo; governing complexity; water scarcity.

RESUMO: O artigo discute a crise da água que ocorreu entre 2013 e 2015 na Região Metropolitana de São Paulo, a falta de planejamento integrado de recursos naturais e a reação dos atores sociais afetados pelos impactos. A região foi afetada por um evento hidrológico e climatológico extremo combinado com um manejo insustentável dos recursos hídricos. O artigo aborda, inicialmente, a dinâmica da governança da água na região e os principais 
aspectos que provocaram a emergência da crise hídrica, atrelados à disponibilidade de água e à dependência climática. Em seguida, é feita uma análise do processo ocorrido e dos principais desdobramentos da crise da água. Nossa análise é baseada no acompanhamento dos diferentes momentos da crise e em diálogos com as partes interessadas, e indica a relevância de enfatizar questões como a falta de transparência, além de destacar o papel das iniciativas da sociedade. Concluímos o artigo propondo a discussão de processos de governança que possam contribuir para o desenvolvimento de iniciativas mais efetivas, a fim de reduzir o impacto dessa mudança visível nos regimes hídricos, fortalecer a gestão transparente e promover uma interação mais democrática entre atores sociais e o governo.

Palavras-chave: governança da água; justiça ambiental; São Paulo; governando a complexidade; escassez hídrica.

\section{Introduction}

Water crises have multiplied in many parts of the planet. Besides those usually affected, the picture has become more recurrent in cities such as São Paulo, Brasília, Rome, Nairobi, and regions like California and Australia (Jacobi et al., 2019). Successive supply crises overlap, making it difficult to replenish water reservoirs fully. As a result, these reservoirs end up with a low volume of stored water, making this new scenario almost permanent (Braga \& Kelman, 2016).

In this article, we propose an analysis of the water crisis in the Metropolitan Region of São Paulo (MRSP) between 2013 and 2015, using as a conceptual framework the approaches of governing complexity and environmental injustice. There is a constant tension in the process of dispute around the decision-making and its outcomes. Hence, it is a challenge to improve equity in the distribution of water in the metropolis and to reduce and balance distortions in this process, strengthening the access to the public water supply system (Ribeiro, 2011; Fracalanza \& Freire, 2015; Rodrigues \& Villela, 2015).

Transparency and accountability are crucial in the process of democratic governance (Frey, 2012).
In a context of the implementation of participative governance, multiple categories of stakeholders, institutions, and inter-relations are involved, each of them representing not only specific arrangements and interests at stake but also possibilities of negotiation (Momm et al., 2013; Travassos \& Schult, 2013; Jacobi et al., 2018).

It's demands interdependencies that indicate the limitations of the government and the need for strong links with local governments, the private sector, and social organizations (Xavier et al., 2019). The challenge is to articulate the actions of different public actors, including watersheds committees, as defined by the Brazilian water legislation. Furthermore, the period between 2013 and 2015 showed that it is no longer possible to govern natural resources on a metropolitan scale with centralized decisions, such as the case of São Paulo. The crisis showed that the interdependence of natural resources related to water supply needs to be addressed on a macro scale, involving stakeholders and extrapolating traditional frontiers and business as usual as paths of planning and management (Zioni et al., 2019; Travassos et al., 2020).

Although the water crisis has affected the majority of São Paulo citizens, the impacts were not felt equally (Fracalanza \& Freire, 2015). The 
most vulnerable populations of the MRSP suffered the hardest effects. The emergence of social groups and actors, in an environmental justice perspective (Acselrad, 2002), was crucial in highlighting the crisis and its impacts on the residents, and in facing the official communication battle with the State Government. In this sense, the article also seeks to contribute to the necessary dialogue between approaches to governance and environmental justice.

\section{Methods}

The article is structured by a literature review on governance and environmental justice, supported by secondary empirical data, which aims to recover the intricacies of the 2013-2015 water crisis in the metropolitan region of São Paulo. The main sources of quantitative data and documents from primary sources were obtained from the São Paulo State Sanitation Company (Sabesp), and the Meteorological Station of the Astronomical and Geophysical Institute of University of São Paulo - (IAG/USP). The secondary sources are from the Climate Prediction Center of the National Oceanic and Atmospheric Administration (CPC/NOAA) and the Research Group on Environmental Governance (GovAmb) of the Institute of Energy and Environment with the NGO Institute of Democracy and Sustainability (IDS).

\section{Water governance in metropolitan São Paulo}

Since 1997, the Brazilian model of water management proposes an integrated, decentralized, and participatory policy framework (Rodrigues \& Ville- la, 2015). This model innovates as it gives power to decentralized water basin institutions and requires a process of negotiation between different public agents, users, and organized civil society (Jacobi, 2004; Jacobi, 2009). The Metropolitan Region of São Paulo is composed of 39 municipalities with a population of over 21 million inhabitants, representing $46 \%$ of the population of the state of São Paulo and 55\% of the state's GDP (IBGE, 2013). Besides the high population density, the region is also marked by the complexity of its urban environment, which presents a high occupation and cluttered and intense use of land (Jacobi, 2013; Travassos \& Schult, 2013).

The population growth in the MRSP (Figure 1) required investments by the State Company of Basic Sanitation of the State of São Paulo (Sabesp) in order to expand the supply system, be it with the increase of the capacity of the treatment plants or with the development of the water sources. Sabesp is a public company with both public and private capital that was founded in 1973 and is currently responsible for providing water and collecting and treating sewage in 366 municipalities of the State of São Paulo (Ribeiro, 2011).

Sabesp is one of the world's largest sanitation companies in terms of population served, since not only it supplies water to 27.9 million people and provides sewage collection services to 21.6 million people, it is also responsible for around $27 \%$ of the investments in basic sanitation in Brazil (SABESP, 2019).

Public water supply in the MRSP is made through eight water treatment plants operated by Sabesp, which is also responsible for the sanitation of 39 of its municipalities, serving more than 20 million people. Analyzing Table 1, it is possible to 
verify that Guaraú, one of the plants, is responsible for the supply of nine million inhabitants, i.e., $45 \%$ of the water consumed (Table 1). The Guaraú treatment station captures water from a system of interconnected water reservoirs called Cantareira ( $\mathrm{Fi}$ gure 2). Thus, the water supply of the Metropolitan Region of São Paulo has a significant dependence on the water reservoirs of the Cantareira system, which are connected to the treatment station of Guaraú. Before the crisis, this system was responsible for supplying the MRSP with $31 \mathrm{~m} 3 / \mathrm{s}$ of water $(45.1 \%$ of the total consumption of MRSP), of which $24.8 \mathrm{~m} 3 / \mathrm{s}$ were used by household consumption.

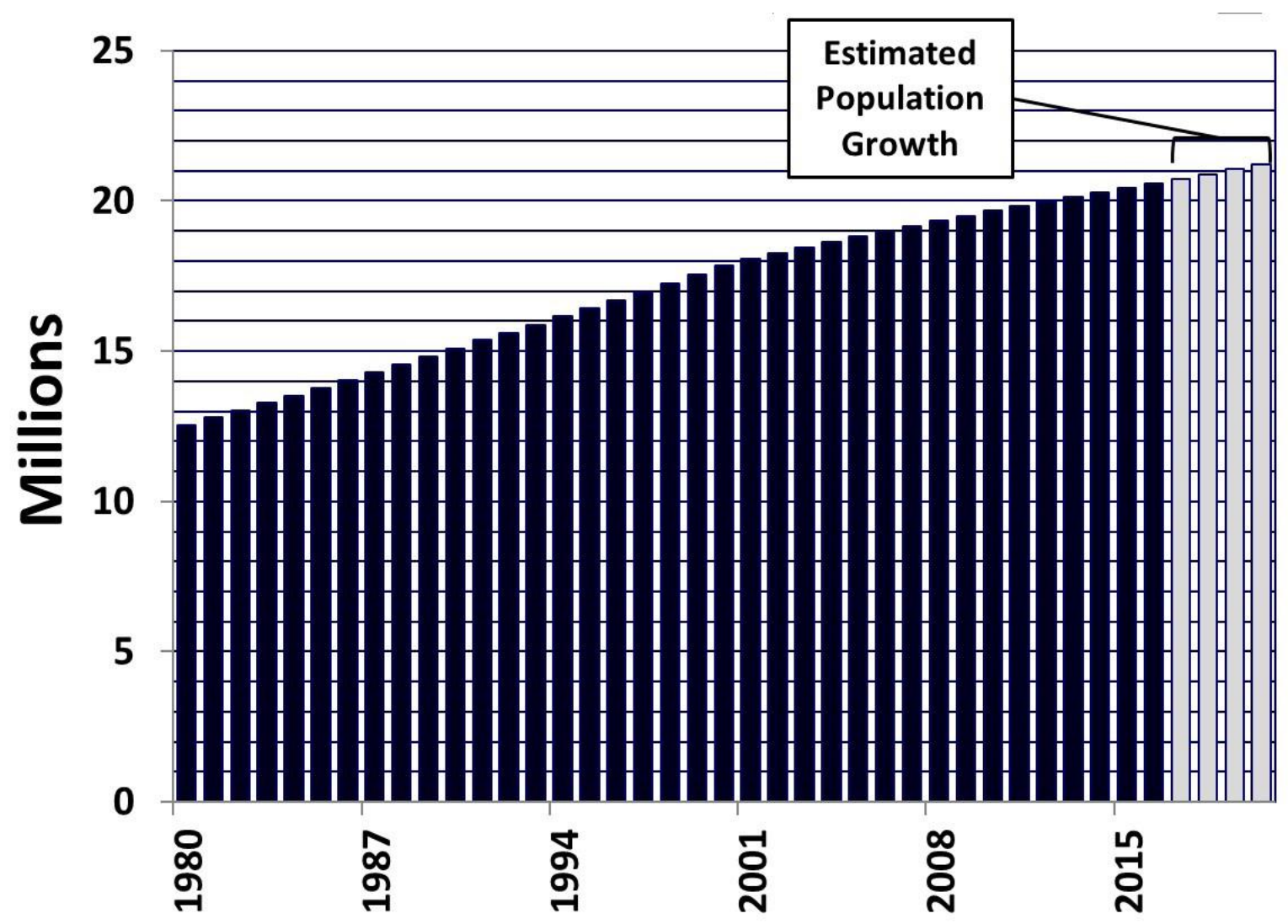

FIGURE 1 - Population Growth in the Metropolitan Region of São Paulo 2004-2012. SOURCE: Adapted from IBGE (2013). 
TABLE 1 - Water Treatment Stations in the Metropolitan Region of São Paulo - Production and Population Served.

\begin{tabular}{lccc}
\hline \multicolumn{1}{c}{ Producer System } & Production $\left(\mathbf{m}^{3} / \mathbf{s}\right)$ & Population Served & $\begin{array}{c}\text { Participation in the amount of water supplied to } \\
\text { (he }\end{array}$ \\
\hline Alto Cotia & 1.2 & 0.41 & $1.64 \%$ \\
Alto da Boa Vista & 14.0 & 3.70 & $19.13 \%$ \\
Baixo Cotia & 0.9 & 0.42 & $1.23 \%$ \\
Casa Grande & 4.0 & 2.06 & $5.46 \%$ \\
Guaraúb & 33.0 & 9.00 & $45.1 \%$ \\
Ribeirão da Estiva & 0.1 & 0.04 & $0.14 \%$ \\
Rio Grande & 5.0 & 1.20 & $6.83 \%$ \\
Taiaçupeba & 15.0 & 3.30 & $20.49 \%$ \\
\hline \multicolumn{1}{c}{ Total } & $\mathbf{7 3 . 2}$ & $\mathbf{2 0 . 1 3}$ & $\mathbf{1 0 0 \%}$ \\
\hline
\end{tabular}

${ }^{a}$ Millions of inhabitants

${ }^{\mathrm{b}}$ Cantareira System treatment plant

SOURCE: Côrtes et al. (2015).

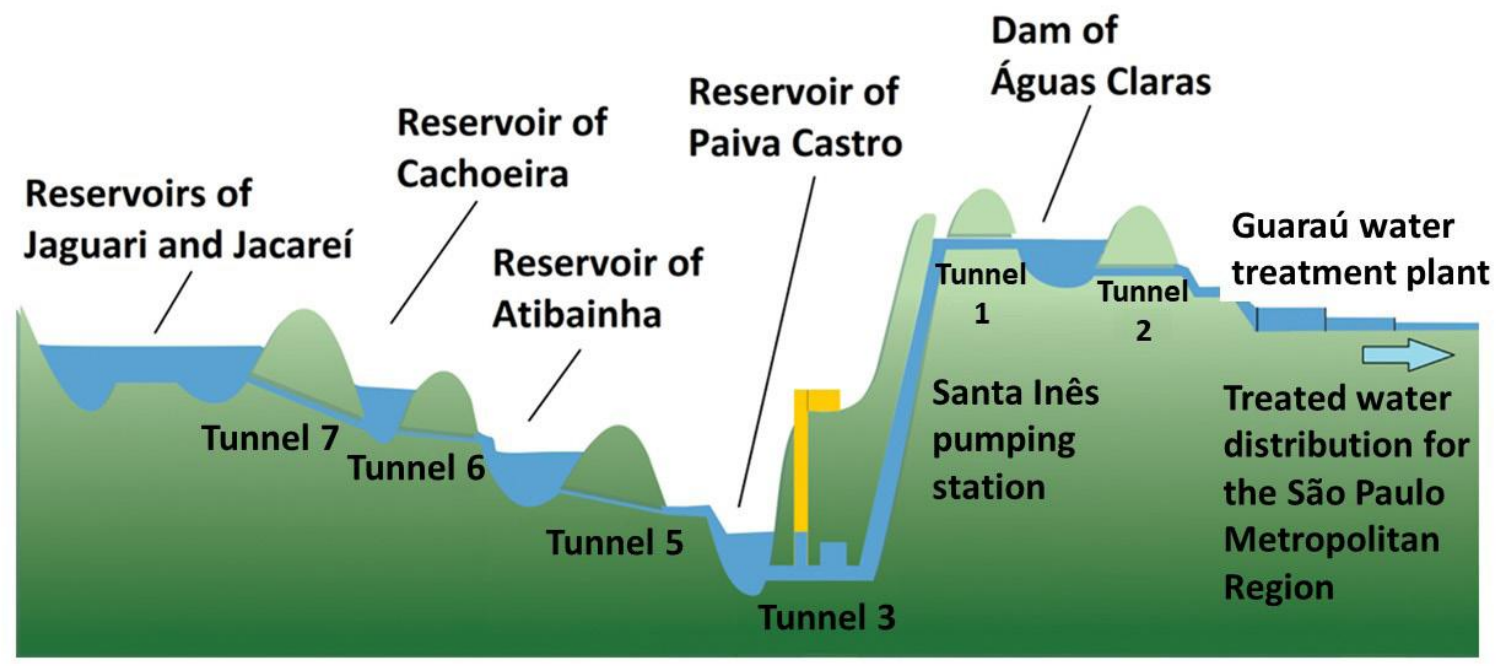

FIGURE 2 - Schematic diagram of the Cantareira System.

SOURCE: Adapted from SABESP (2006; 2007; 2008; 2009a; 2009b; 2009c; 2011; 2012). 


\section{Water availability and climate dependence in the metropolitan region of São Paulo}

Since 1950, seven periods of more pronounced shortages have occurred (Figure 3). It shows that reductions in the annual volume of rainfall are not rare situations and should be considered in the planning of the supply system of the Metropolitan Region of São Paulo. It is interesting to verify, however, the behavior of the supply system during the two most recent crises. The penultimate dates back to 2003 - 2004, and the last one started in 2013. These cycles are related to the El Niño-Southern Oscillation (ENSO), as shown by Côrtes et al. (2015) and discussed later in this paper.

More recently, between January 2005 and December 2012 (the period between the two most recent crises), the system was working under normal conditions (Figure 4). Taking the monthly water averages available to the population into consideration, it is revealed that the system has always worked close to the operational limit or, sometimes, above it. Figure 4 shows that the supply system worked at the very least, requiring $93 \%$ of its operational capacity (working with a gap of only $7 \%$ ). Considering this as a normal situation, we must inquire how the system would work in case of more prolonged or more intense droughts. Since the system, in a normal situation, works very close to its full operational capacity, it cannot withstand a more significant reduction in the volume of rainfall. There would be no operational gap because of the low elasticity of the system.

As shown in Figure 4, in the ten years before the last supply crisis, the water supply system of the MRSP worked very close to its operational limit.
Thus it is possible to affirm that this system cannot withstand climatic events such as more severe droughts or more extended rainfall reductions. It evinces the importance of investigating climate issues. The analysis of the system levels since 2004 (Figure 5) demonstrates that the recharge period occurs from October to March of each year. Since 2011 until the beginning of the crisis in 2013, however, there has been a reduction in the system-level re-composition, represented by the straight line $(\mathrm{AB})$ in Figure 5. The maximum volume was below the level obtained in the previous year, which could have been used for the design of preventive measures (Galpin \& Whittington, 2012; Galbreath, 2014).

A study conducted by Côrtes et al. (2015) shows that the dams recharge periods with a predominance of the El Niño phase present higher rainfall volume for the city of São Paulo. According to the study, it is during El Niño that the rainy season extends until autumn (a season traditionally drier) and expands the recharge of the Cantareira System (Côrtes et al., 2015). The period of most considerable decrease in the volume of the System (represented by the line $\mathrm{AB}$ in Figure 5) occurs predominantly in a neutral phase of the ENSO phenomenon, which was verified in the period from April 2012 to April 2013.

Figure 6 shows that throughout 2009, with the presence of the La Niña phase of the ENSO phenomenon, there was a decrease of almost $30 \%$ in the Cantareira System level. However, it was rapidly recovered in 2010 with the beginning of the El Niño phase, which remained intense until the middle of the second half of that year. As a result, the decrease in the Cantareira System-level was approximately $25 \%$ in 2010 (5\% less than the prior year). From 2011 onwards, with the predominance of the La 
Niña phase, and with brief periods of ENSO neutral phase, the re-composition of the System-level was lower than the previous year, given evidence of the tendency to reduce the volume stored, as indicated by the line AB in Figure 6 .

Figure 7 contributes to the understanding of this scenario through a comparison between the phases of the ENSO phenomenon and the inlet of water (recharge) of the Cantareira System. This figure presents a vital reference value: the average annual water intake of the Cantareira System for the year 1953. Before the recent crisis, this year represented the worst scenario known. The orange arrows in Figure 6 show the episodes in which this reference line was reached or even crossed from 2009. It is possible to verify that all these episodes are related to a weaker La Niña phase or a neutral phase of the ENSO phenomenon. Besides, it is noted that, especially from May 2013 onwards, this line was crossed, and the water inlet became lower than the reference line. This scenario remained so due to the predominance of the neutral phase of the ENSO phenomenon.

The red line at the top of Figure 7 shows the use of water from the Cantareira System. In many cases where the water inlet (represented by the blue line) was reduced, the outlet remained higher. It occurred in particular from May 2013 onwards, with a brief interruption at the beginning of 2015 . It contributed to a drastic reduction in the volume of the dams in the Cantareira System, aggravating the scenario of scarcity. It shows that the problem of strategic management of the system existed before the crisis (when climatic influences on the functioning of the System were ignored) and during the crisis (when the outlet was maintained higher than the water inlet). In May 2013, the water inlet became very low, and the climatic prognoses indicated a higher probability of occurrence of the ENSO neutral phase, as indicated by Figure 8 .

Both the dynamic and statistical models indicated that the temperature anomaly on the surface of the Pacific Ocean in the El Niño 3.4 region would remain between $-0.5{ }^{\circ} \mathrm{C}$ and $+0.5{ }^{\circ} \mathrm{C}$, predicting the occurrence of a neutral phase. This prognosis was confirmed, leading to a significant reduction in the water inlet of the Cantareira System. If this forecast had been taken into account at that point, the use of water from the Cantareira System would have been reduced, thus preserving the conditions of the reservoirs.

\section{Development of the water crisis}

Although the levels of the Cantareira System and climate forecasts consistently indicated the existence of problems since May 2013, it was only at the beginning of 2014 that the State Government of São Paulo would acknowledge the existence of a water supply crisis (Côrtes, 2017). As the water outlet did not suffer a significant reduction, being above the water inlet in the System, the water level dropped rapidly. In May 2014, the level of two reservoirs was deficient, making it impossible to transfer their content by gravity to a third reservoir. What remained in these reservoirs consisted of a volume intended to accommodate sediment and whose exploitation was not foreseen. Once called "dead volume," this reserve was renamed "technical reserve" by the government technical team. It was a communication strategy aimed at smoothing the impacts of the crisis because the government tried to convince the population that this was a strategic 


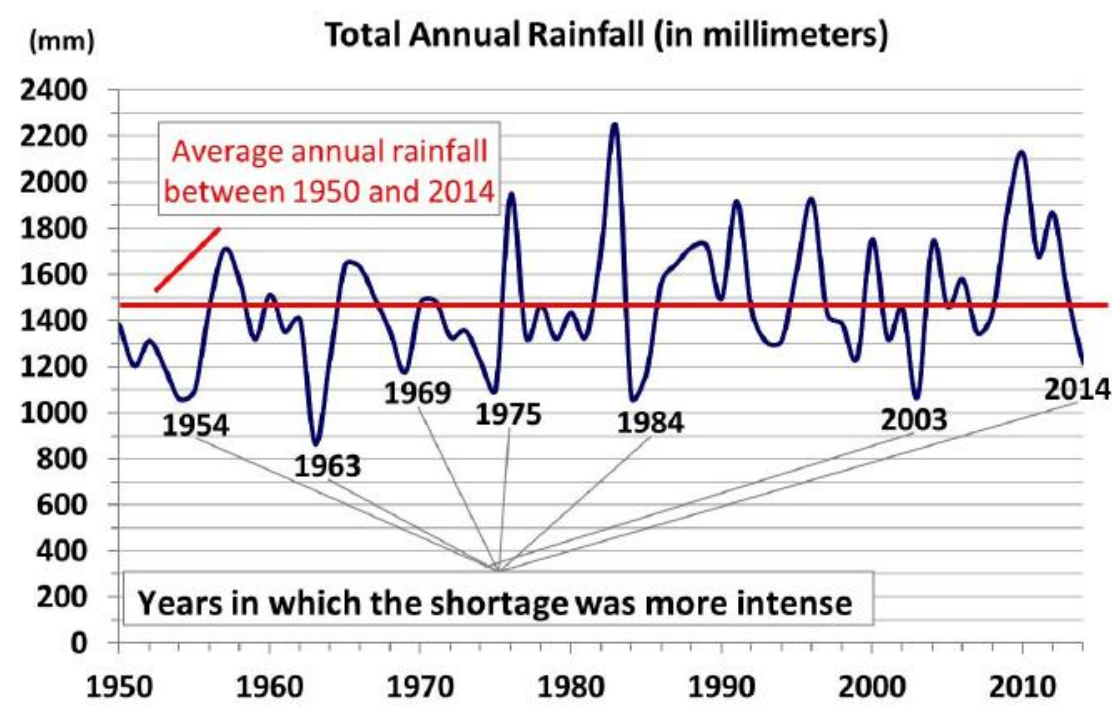

FIGURE 3 - Total annual rainfall in the city of São Paulo between 1950 and 2014.

SOURCE: Elaborated by the authors from data provided by the Astronomical and Geophysical Institute of the University of São Paulo.

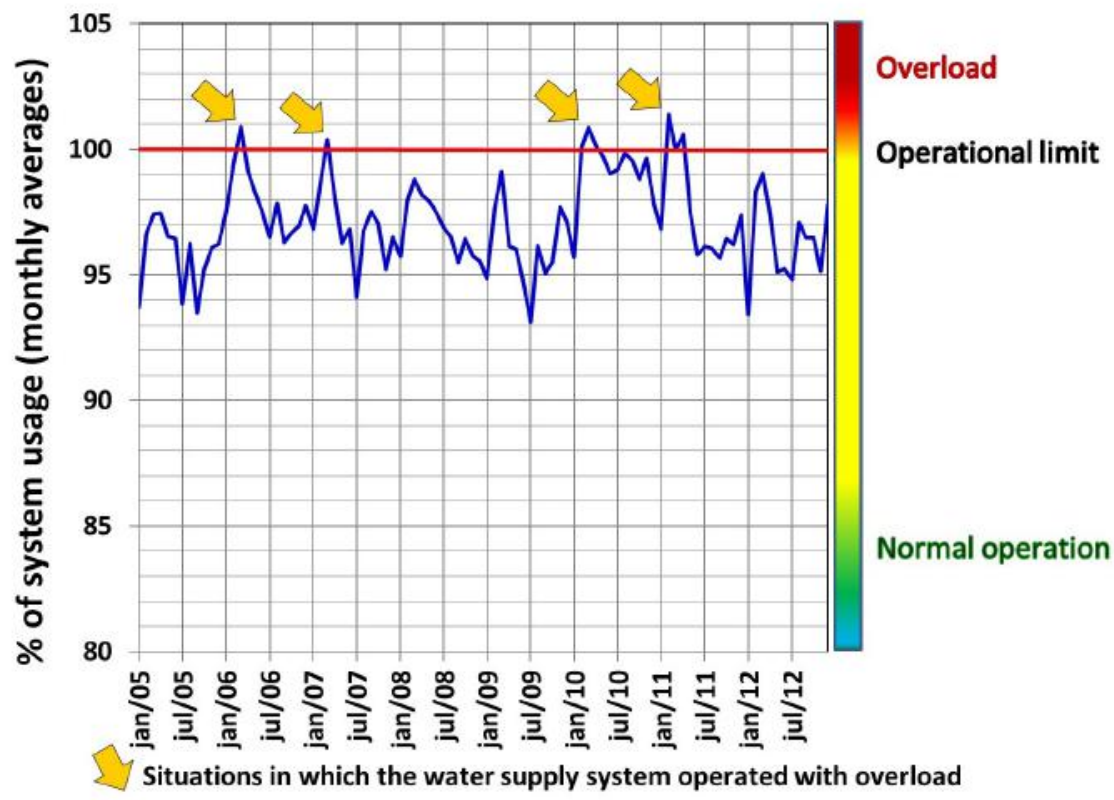

FIGURE 4 - Operational situation of the water supply system in the Metropolitan Region of São Paulo between 2004 and 2012 based on the average monthly volumes.

SOURCE: Adapted from SABESP (2006; 2007; 2008; 2009a; 2009b; 2009c; 2011; 2012). 


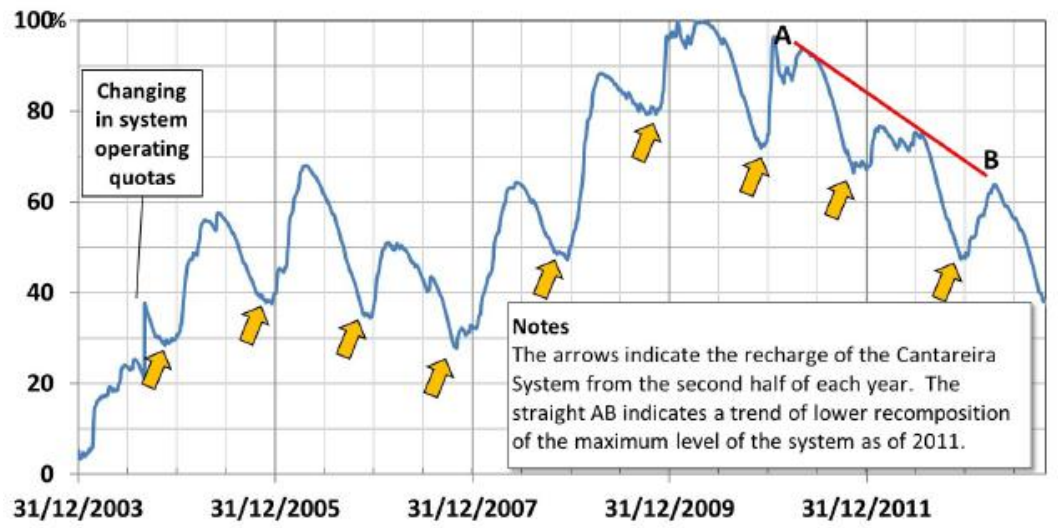

FIGURE 5 - Evolution of the Cantareira System volume between 2004 and 2014.

SOURCE: Adapted from National Water Agency (2014, p. 9).

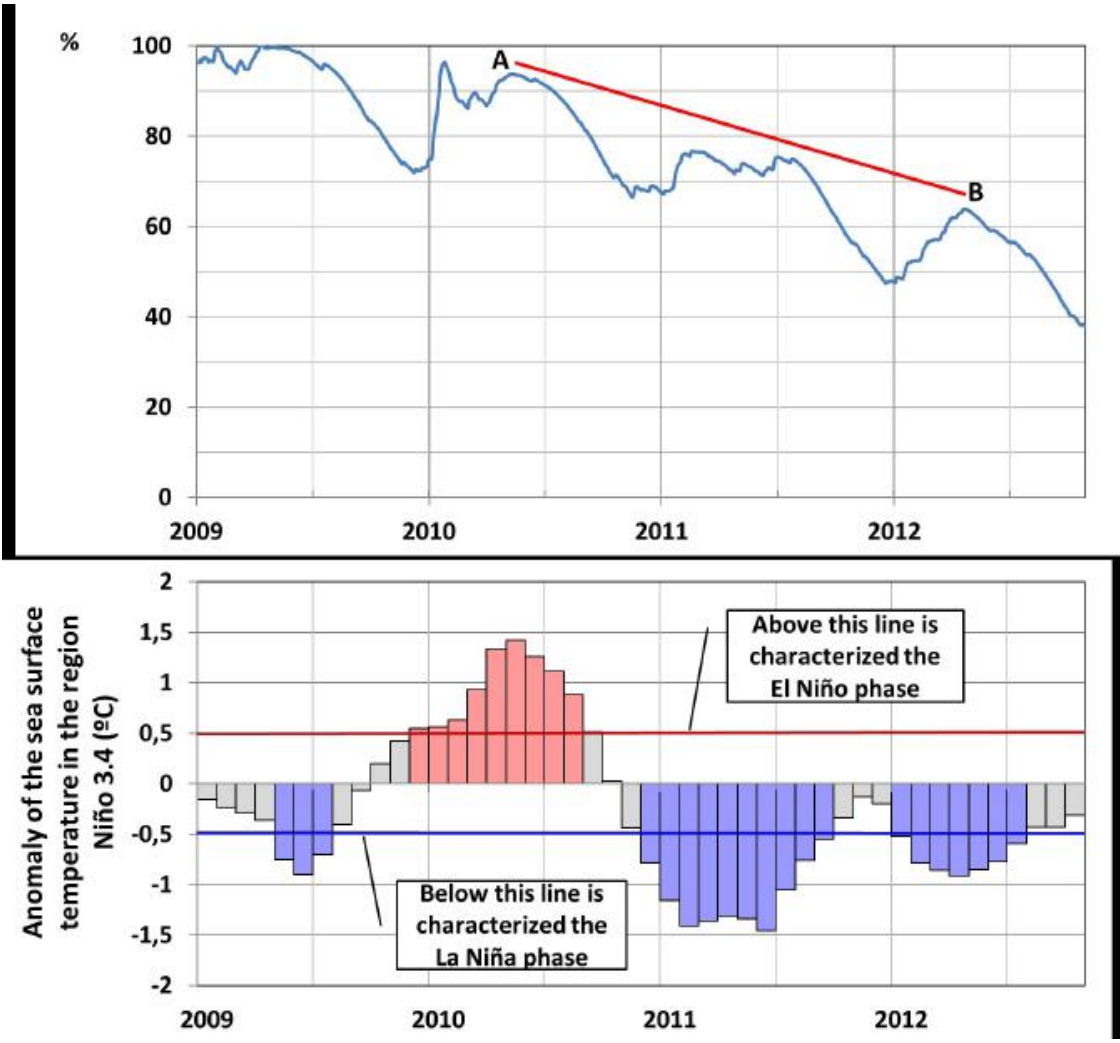

FIGURE 6 - Correlation between the phases of the ENSO phenomenon and the level of the Cantareira System in the years prior to the water crisis. SOURCE: Elaborated by the authors based on data from the National Water Agency (2014) and data from the Climate Prediction Center of the National Oceanic and Atmospheric Administration (CPC/NOAA). 

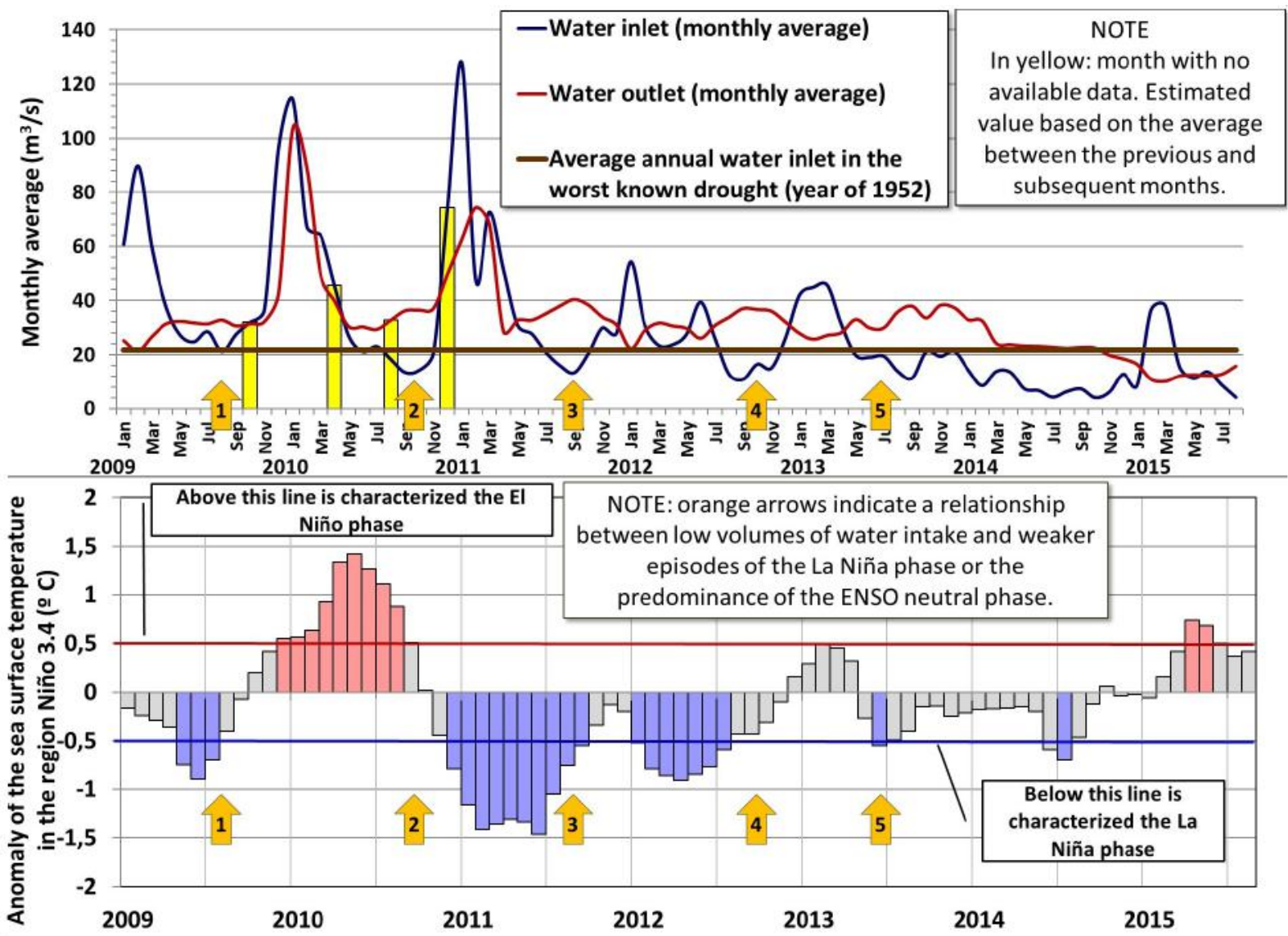

FIGURE 7 - Correlation between the phases of the ENSO phenomenon and the water intake and outflow of the Cantareira System (2009 to mid-2015)

SOURCE: Elaborated by the authors based on information from the National Water Agency (2014). 


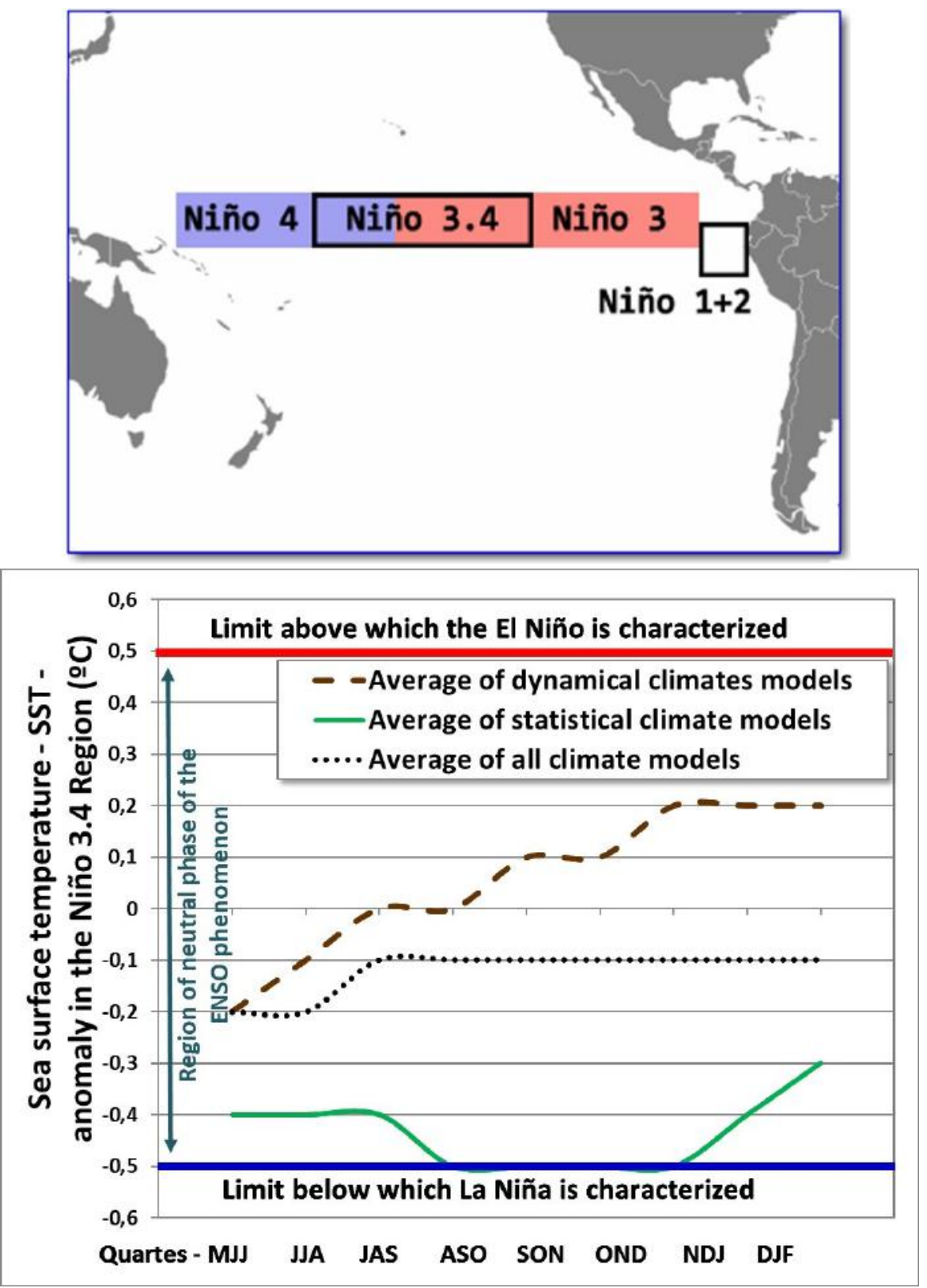

FIGURE 8 - Forecast of the ENSO phenomenon from the May/June/January (MJJ) quarter of 2013 to the January/February/March (JFM) quarter of 2014.

SOURCE: Elaborated by the authors with data from the International Research Institute for Climate and Society (Earth Institute) - Columbia University. Available on: http://iri.columbia.edu/our-expertise/climate/forecasts/enso/archive/201305/SST_table .html 
reserve for times of crisis. Therefore, the "dead volume" - originally intended not to be used - was incorporated into the Cantareira System, artificially increasing its levels (Côrtes, 2017).

The crisis showed the fragility of the system of water governance in the Metropolitan Region. It highlighted decades of inadequate practices of water management, mainly linked to the bad quality of some waterways resulting from the no conclusion of the primary sewage treatment system that has been very delayed, directly implying in the impossibility of its use to supply the population. Desirable democratic governance initiatives were not tackled, as the action of the state government was not transparent, and not only the water basin committees but also the State Council of Water Resources were undermined from discussions and decision-making process to confront the crisis (Jacobi et al., 2015).

The lack of transparency and accountability is manifested mainly when the state does not promote initiatives that stimulate the co-responsibility of the population, as authorities masked the crisis until the moment when it was not possible to do it anymore. Decisions were taken at the central level of government - i.e., linked directly to the governor (Côrtes, 2017). The main reason was the interference of an electoral agenda at the state and federal levels, and the government did not want to take an anti-popular position by promoting a preventive turnover, notwithstanding the situation was becoming extreme (Côrtes, 2017). Besides that, peripheral neighborhoods and settlements lived under constant interruptions of water supply. However, the water management company affirmed that there were no abnormalities in the supply (Fracalanza $\&$ Freire, 2015). It reinforces that, in addition to wrong political decisions, the system suffers from structural problems.

The leading cause for the worst water crisis in the region emphasized by the government of São Paulo and by part of the media was the lack of rain in the summer of $2013 / 2014^{1}$. It has to be noted that since the end of 2013, the level of the reservoirs had been falling due to climatic factors, but other aspects also led to the critical situation of the reservoirs (Coutinho et al., 2015).

It is also essential to take into account that deforestation and inadequate land use in watershed areas (Coutinho et al., 2015), the lack of planning for the construction of new reservoirs, the lack of investments to reduce leaking that attain around $30 \%$ (SABESP, 2019), and the lack of institutional coordination are other relevant causes of the crisis (Rodrigues \& Villela, 2015).

Government strategies were used, emphasizing mainly the reduction of the pressure in the water distribution system. The reduction of pressure, according to Sabesp, is a common practice of sanitation companies to reduce water leakages. During the water crisis, Sabesp intensified this process in order to confront the water scarcity and to avoid, according to the information available on their website, the exhaustion of its reservoirs and to contribute to the maintenance of supply until the normality of rain was recovered.

\footnotetext{
${ }^{1}$ Analysis developed by the Research Group GovAmb of the Institute of Energy and Environment of the University of São Paulo (IEE/USP) in partnership with the NGO Institute Democracy and Sustainability (IDS). Available on: http://www.idsbrasil.org/iniciativa/2/
} 


\section{Denouncing the crisis: environmental justice and resistance}

During the crisis, water rationing occurred in several municipalities of the São Paulo Metropolitan Region. These interruptions could last from several hours to several days in some neighborhoods. The government preferred to call these two actions "water restriction" rather than to use the term "rationing" - these semantic strategies aimed at poorly informing people and sought to minimize negative perceptions among the population.

During the crisis, the educational actions undertaken by Sabesp were minimal. There were no instructions on ways to save water, no explanation about techniques for reusing water, or information about possibilities regarding the collection of rainwater. The impression was that Sabesp feared that consumption would remain low after the crisis and damage their profits (Côrtes, 2017).

One strategy applied by Sabesp was the reduction of the tariff per cubic meter if the consumption was lower than the average. On the other hand, the tariff was increased for consumers who did not reduce their consumption. However, the practice of granting price reduction as an incentive to moderate usage ended when the government considered that the crisis was over in early 2015. In this context, preventive and adaptive management should have been done once the water vulnerability of the region was diagnosed.

However, public officials ignored the collaborative and integrated management of urban water sources and participatory governance. The officials prioritized emergency actions to interconnect the supply systems, disregarding social and environ- mental issues, and the environmental licensing process (Jacobi et al., 2015).

The decision-making process that structured the emergency actions were conducted without consulting the water basin committees, what created conflicts with other states, such as Rio de Janeiro, since part of the solutions involved the Paraiba do Sul river, belonging to the watershed located between the states of São Paulo and Rio de Janeiro (Côrtes, 2017). These public actions were defined without any debate, and the questioning of the civil society was ignored.

As can be seen, the process was politically incoherent, for there was a lack of transparency in the communication of the measures taken regarding the crisis as well as centralization in decision-making. The state government consistently denied the magnitude of the crisis and thus hindered the involvement of society, which could not confront it. Thus, as well as the fact that no water basin committee was taken into account, was a justification for initiatives of different articulations of NGOs and community organizations (Jacobi et al., 2015).

Through a historical analysis, the refractory position of the state government on publicizing the crisis is evident (Côrtes et al., 2015). The daily bulletins on the volume of water in reservoirs were questioned continuously, and at a particular moment of the crisis, in April 2015, the Public Prosecution at the Federal and the State levels determined that the adequate volume of water of the Cantareira reservoir should be disclosed, disregarding the dead volume. This intervention was needed to highlight existing problems and force the state government to take the right steps to address the water crisis. There was a lack of communication and dialogue, as well as 
proposals and information, which made it difficult for different stakeholders to debate (Côrtes, 2017).

Throughout the crisis, the State Government emphasized that the main reason for the crisis was related to climatic factors, and made practically no reference to the existing system of governance and its relation to the problem (IAG, 2014). The civil society noticed the critical situation of the region in 2015 and got mobilized, not only to show awareness of the lack of management, but also the detection of lack of governance and, in this scenario, discovered opportunities of action (Jacobi et al., 2015).

Grassroots and non-governmental organizations developed activities, actions, initiatives, and projects to inform the population, focusing on the actions of public officials and working cohesively for water governance by promoting a new culture of water conservation (Jacobi et al., 2015). The movements and articulations of NGOs developed strategies to denounce the crisis. They pressured authorities to allow the participation of civil society with propositions and solutions, in order to guarantee equity in the access of water and to expand the channels of mobilization and denouncement of environmental injustice (Fracalanza \& Freire, 2015; Ribeiro, 2017).

Specialists of the field already anticipated the possibility of an extremely critical situation for at least a decade, especially in São Paulo, where an upcoming shortage of water in a level that consumption would exceed water availability was already expected (Empinotti et al., 2018, Klink et al., 2019). In São Paulo, during the crisis of 2013-2015, the decreases in rainfall in the southeastern region of Brazil presented a predictable scenario of water scarcity for 2014-2015. However, it is essential to note that, in addition to difficulties related to hydro- logical cycles and water availability, human-made factors also interfered in the quality and quantity of the resource: inland sewage disposal, the effects of climate change on water production and the lack of investments to improve water storage and distribution infrastructure for governing complexity (Thiel et al., 2019).

The lack of governance regarding the water management system was already envisaged by specialists since the end of the $1980 \mathrm{~s}$, as recommendations were made to increase water availability in the region and less dependency on water import from neighboring watersheds. In 2004, the Department of Water and Electric Energy (DAEE) responsible for the management of water resources and coordinator of the integrated system of the State of São Paulo recommended a set of actions to increase water availability. The NGO Article 19 concluded that the transparency of the State of São Paulo on the water management system was insufficient and lacked in broadening channels of information and in providing data quality (Empinotti et al., 2018).

\section{Preliminary conclusions}

The MRSP water crisis caused impacts of different levels, ranging from the interruption of water supply in municipalities to the negative impacts on aquatic ecosystems of reservoirs and waterways. The lack of capacity of the state government to articulate preventive and adaptive actions exposes, in practice, a decision-making process that does not take into account adequately the integration of different environmental public policies - e.g., water supply, sanitation, climate change and protection of areas surrounding watersheds. 
With a technical and centralizing discourse, remarking that the main reason for the crisis was the lack of rain, authorities removed any integration and dialogue with the population. The perception that the hydric crisis was mainly a management problem was strengthened by the fact that the government of São Paulo lacked transparency on their stance. Furthermore, the water management system is shown as unprepared for the effects of climate change, which tend to be more frequent and reach mainly the poorest sections of the population (Torres \& Leonel, 2019).

One of the most significant challenges in governing complexity is to include environmental justice paradigms, anticipatory actions, and transparency in governmental planning and public policies. It implies not only changes in the system of accountability to society by public and private managers but also in cultural and behavioral changes.

\section{Acknowledgments}

The São Paulo Research Foundation supported this study (FAPESP), with the Process 2018/066859 and 2019/05644-0, which is part of the Thematic Project MacroAmb "Environmental Governance in São Paulo Macrometropolis in a climate variability context," 2015/03804-9. The authors would also like to thank the reviewers and their suggestions, which helped to improve this paper.

\section{References}

Acselrad, H. Justiça Ambiental e Construção Social do Risco. Desenvolvimento e Meio Ambiente, 5, p. 49-60, 2002.

Braga, B.; Kelman, J. Facing the challenge of extreme cli- mate: The case of Metropolitan São Paulo, Water Policy, 52-69, 2016.

Côrtes, P. L. Antecedentes que Levaram à Crise Hídrica do Sistema Cantareira na Região Metropolitana de São Paulo. In: Jacobi, P. R; Fracalanza, A. P.; Empinotti, V. (Org.). Governança da Água no Contexto da Escassez Hídrica. São Paulo: Instituto de Energia e Ambiente - USP, 1, p. 91-113, 2017.

Côrtes, P. L.; Torrente, M.; Alves Filho, A.P. et al. Crise de abastecimento de água em São Paulo e falta de planejamento estratégico. Estudos Avançados, 29(84), 7-26, 2015.

Coutinho, R.; Kraenkel, R.; Prado, P. Catastrophic Regime Shift in Water Reservoirs and São Paulo Water Supply Crisis, PLoS ONE, 10(9), e0138278, 2015. doi: 10.1371/ journal.pone. 0138278

Empinotti, V.; Budds, J.; Aversa, M. Governance and water security: The role of the water institutional framework in the 2013-15 water crisis in São Paulo, Brazil. GEOFORUM, 98, 46-54, 2018.

Fracalanza, A.; Freire, T. M. Crise da água na Região Metropolitana de São Paulo: a injustiça ambiental e a privatização de um bem comum. Geousp (USP), 19, 464-478, 2015.

Frey, K. Abordagens de governança em áreas metropolitanas da América Latina: avanços e entraves. Urbe - Revista Brasileira de Gestão Urbana, 4, 87-102, 2012.

Galbreath, J. Climate change response: Evidence from the margaret river wine region of Australia, Business Strategy and the Environment, 23, 89-104, 2014.

Galpin, T.; Whittington, J.L. Sustainability leadership: From strategy to results. Journal of Business Strategy, 33, 40-48, 2012.

IAG - Instituto de Astronomia, Geofísica e Ciências Atmosféricas. Relatório de Dados Climatológicos da Cidade de São Paulo - (período 1950 - 2014). São Paulo: IAG-USP, 2014.

IBGE - Instituto Brasileiro de Geografia e Estatística. Estimativas da população residente nos municipios brasileiros com data de referência de $1^{\circ}$ de julho de 2013. Brasília: IBGE, 2013. 
Jacobi, P. R. Governança da Água no Brasil. In: Ribeiro, W. (Org.). Governança da água no Brasil - Uma visão interdisciplinar. São Paulo: Editora Annablume, 2009. p. 37-54.

Jacobi, P. R. São Paulo metrópole insustentável - como superar esta realidade. Cadernos Metrópole, 15, 219-239, 2013.

Jacobi, P. R. The challenges of multi-stakeholder management in the watersheds of São Paulo. Environment and Urbanization, 16(2), 199-211, 2004.

Jacobi, P. R.; Cibim, J. C.; Leão, R.S. Crise hídrica na Macrometrópole Paulista e respostas da sociedade civil. Estudos Avançados, 84, 27-42, 2015.

Jacobi, P. R.; Empinotti, V.; Grandisoli, E. Alternativas para o futuro da água em São Paulo. In: Buckeridge, M.; Ribeiro, W. (Org.). Livro branco da água. A crise hídrica na Região Metropolitana de São Paulo em 2013 -2015: Origens, impactos e soluções. São Paulo: Instituto de Estudos Avançados- Universidade de São Paulo, 1, p. 101-121, 2018.

Jacobi, P. R.; Torres, P. H.; Greese, E. Governing Shallow Waters: SDG 6 and Water Security in Sao Paulo. In: UNESCO i-WSSM. (Org.). Water Security and the Sustainable Development Goals. Global Water Security Issues (GWSI) Case Studies, UNESCO i-WSSM, Daejeon. Daejeon: UNESCO i-WSSM, 1, p. 1-150, 2019.

Klink, J.; Empinotti, V.; Aversa, M. On contested water governance and the making of urban financialisation: Exploring the case of metropolitan São Paulo, Brazil. Urban Studies, 1, 198-217, 2019.

Momm-Schult, S. I.; Piper, J.; Denaldi, R.; Freitas, S. R.; Fonseca, M. L. P.; Oliveira, V. E. Integration of Urban and Environmental Policies in the Metropolitan Area of São Paulo and in Greater London: the value of establishing and protecting green open spaces. International Journal of Urban Sustainable Development, 5, 89-104, 2013.

National Water Agency. Conjuntura dos Recursos Hidricos no Brasil - Informe 2014 - Encarte Especial sobre a Crise Hídrica. National Water Agency of Brazil, 2014.

Ribeiro, W. Water supply and water stress in the Metropolitan Region of São Paulo. Estudos Avançados, 25(71), 119-133, 2011.

Ribeiro, W. Justiça espacial e justiça socioambiental: uma primeira aproximação. Estudos Avançados, 31, 147-165, 2017.

Rodrigues, C.; Vilella, F. N. J. Disponibilidade e escassez de água na Grande São Paulo: elementos-chave para compreender a origem da atual crise de abastecimento. Geousp - Espaço e Tempo, 19(3), 399-421, 2015.

SABESP - Companhia de Saneamento Básico do Estado de São Paulo. Securities and Exchange Commission dos Estados Unidos. Formulário 20F 2005, São Paulo: SABESP, 2006.

SABESP - Companhia de Saneamento Básico do Estado de São Paulo. IAN - Informações Anuais à Comissão de Valores Mobiliários. São Paulo: SABESP, 2007.

SABESP - Companhia de Saneamento Básico do Estado de São Paulo. Securities and Exchange Commission dos Estados Unidos. Formulário 20F 2007. São Paulo: SABESP, 2008.

SABESP - Companhia de Saneamento Básico do Estado de São Paulo. Financial Statement 2009-CVM Fillings. Management report: 3rd quarter financial information. São Paulo: SABESP, 2009a.

SABESP - Companhia de Saneamento Básico do Estado de São Paulo. Relatório operacional de julho de 2009 da Unidade de Negócio de Produção de Água da Metropolitana. São Paulo: SABESP, 2009b.

SABESP - Companhia de Saneamento Básico do Estado de São Paulo. Formulário 20-F. Relatório anual de acordo com o artigo 13 ou 15(d) da Lei de Valores Imobiliários de 1934 referente ao exercício social encerrado em 31 de dezembro de 2009. São Paulo: SABESP, 2009c.

SABESP - Companhia de Saneamento Básico do Estado de São Paulo. Formulário 20-F 2011. Relatório anual de acordo com o artigo 13 ou 15(d) da Lei de Valores Imobiliários de 1934 referente ao exercício social encerrado em 31 de dezembro de 2011. São Paulo: SABESP, 2011.

SABESP - Companhia de Saneamento Básico do Estado de São Paulo. Formulário 20-F 2012. Relatório anual de acordo com o artigo 13 ou 15(d) da Lei de Valores Imobiliários de 1934 referente ao exercício social encerrado em 31 de dezembro de 2012. São Paulo: SABESP, 2012. 
SABESP - Companhia de Saneamento Básico do Estado de São Paulo. Investors Relation - Profile. Available on: <http:// www.sabesp.com.br/CalandraWeb/CalandraRedirect/?temp $=4 \&$ proj $=$ investorsnew $\&$ pub $=\mathrm{T} \& \mathrm{db}=\&$ docid $=71 \mathrm{~F}$ 4969B84C2B981832576A1003EB0F3\&docidPai $=20 \mathrm{~F} 00$ 7048600A1178325769000748F7B >. Access on: nov. 2019.

Thiel, A.; Garrick, D.; Blomquist, W. A. Governing complexity: analyzing and applying polycentricism. Cambridge, United Kingdom; New York, NY, USA: Cambridge University Press, 2019.

Torres, P.; Leonel, A, L. Adaptar pra quem e como? Adaptação e justiça ambiental na Macrometrópole Paulista. In: Torres, P. H. C.; Jacobi, P. R.; Barbi, F.; Gonçalves, L. (Org.). Governança e Planejamento Ambiental: Adaptação e Políticas Públicas na Macrometrópole Paulista. Rio de Janeiro: Letra Capital, 1, p. 3-34, 2019.
Travassos, L.; Schult, S. Recuperação socioambiental de fundos de vale urbanos na cidade de São Paulo, entre transformações e permanências. Cadernos Metrópole, 15(29), 289-312, 2013.

Travassos, L.; Torres, P. H. C.; Zinoi, S.; Ferneandes, B.; Machado, G. Heterogeneidade e fragmentação espacial na Macrometrópole Paulista: a produção de fronteiras e buracos. Ambiente \& Sociedade, 23, e0101, 43-54, 2020.

Xavier, L. Y.; Jacobi, P.R.; Turra, A. Local Agenda 21: Planning for the future, changing today. Environmental Science \& Policy, 101, 7-15, 2019.

Zioni, S.; Travassos, L. R. F. C.; Momm, S.; Leonel, A. L. A Macrometrópole Paulista e os desafios para o planejamento e gestão territorial. In: Torres, P.; Jacobi, P. R.; Barbi, F.; Gonçalves, L. R. (Org.). Governança e Planejamento Ambiental: adaptação e políticas públicas na Macrometrópole Paulista. Rio de Janeiro: Letra Capital, p. 90-99, 2019. 